\title{
'ISLANDS OF EMPOWERMENT': ANTI-DISCRIMINATION LAW AND THE QUESTION OF RACIAL EMANCIPATION
}

\author{
Faisal Bhabha*
}

In her evocative masterpiece, The Alchemy of Race and Rights, published in 1991, Patricia Williams captured a moment in American legal thought that marked a turning point in expressions about race and power, and the implications for social equality. It contained lessons extending beyond America's unique race history, to the general social and political dynamics in liberal democracy that create conditions of privilege and exclusion. She invited us to think about the place of law in the social and institutional practices that sustain status quo hierarchies, despite proclaimed civil rights commitments to justice. She also inspired hope that the role of the lawyer could be one of mutinous agitator-struggling from the inside, using the tools and skills of practice to support the causes of identifiable communities and social movements.

Dans son chef-d'œuvre évocateur, The Alchemy of Race and Rights, publié en 1991, Patricia Williams a saisi un moment dans la pensée juridique américaine qui a marqué un tournant au niveau des expressions concernant la race et le pouvoir, ainsi que les répercussions pour l'égalité sociale. L'ouvrage contenait des leçons qui allaient au-delà de l'histoire raciale unique des États-Unis et qui abordaient la dynamique sociale et politique générale de la démocratie libérale qui crée des conditions de privilège et d'exclusion. L'auteure nous a invités à examiner la place du droit dans les pratiques sociales et institutionnelles qui maintiennent les hiérarchies du statu quo, malgré les engagements en matière de droits civils qui ont été pris en faveur de la justice. Elle a aussi laissé espérer que l'avocat pourrait jouer un rôle d'agitateur rebelle — luttant de l'intérieur, en utilisant les outils et compétences pratiques pour soutenir les causes des collectivités et des mouvements sociaux identifiables.

\section{INTRODUCTION}

In her evocative pièce de résistance, The Alchemy of Race and Rights, published in 1991, ${ }^{1}$ Patricia Williams captured a moment of intensity in expressions about race and power in American legal thought, and its implications for social equality. She exposed the pretensions of objectivity in law as experienced by racial minorities, and challenged the rigid structures of legal doctrine, which she showed reduce human experiences to too-neat categories and over-simplifications. She invited readers to think

* Osgoode Hall Law School, York University. The author was a vice-chair with the Human Rights Tribunal of Ontario between 2008-2011. The opinions expressed in this article are his alone. He thanks Danielle Cornacchia for dependable research assistance. He also thanks the organizers and participants in the symposium, Contemporary Accounts of Racialization in Canada: Re-igniting Critical Race, held at Osgoode Hall Law School in Toronto in November 2012, and in particular Patricia Williams for inspiring a rich day of discussion and reflection.

1 Patricia J Williams, The Alchemy of Race and Rights (Cambridge, MA: Harvard University Press, 1991). 
critically about rights in relation to the lingering racial privileges and unearned advantages that pervade social relations, norms and institutions, including the teaching and practice of law. The insight from her analysis extended beyond the context of America's unique history with its black minority. It spoke to the social and political dynamics at play in many liberal democracies, where conditions of privilege and exclusion intersect with, or are driven by, the politics of racialization. Williams compelled us to think about the place of law in the social and institutional practices that sustain structural inequality, despite proclaimed civil rights commitments to social justice. She also inspired hope that the role of the lawyer could be one of mutinous agitator - using knowledge, skills, creativity, experience and, when necessary, defiance - to support the causes of those excluded from equal benefit and protection of the law.

With the enactment of civil rights legislation in the United States in the early 1960s, ${ }^{2}$ African Americans gained a legal instrument with which to remedy their history of race-based exclusion. Similarly, in Canada, the adoption of provincial and federal human rights statutes created processes for investigating, adjudicating and vindicating claims of discrimination in a racial landscape that, from the 1960s onwards, would diversify as a result of liberalized federal immigration and multiculturalism policies. $^{3}$

In Ontario, the Human Rights Code turned 50 in 2012. ${ }^{4}$ The Code is premised on the notion that the "inherent dignity and the equal and inalienable rights of all members of the human family is the foundation of freedom, justice and peace in the world." To this end, it promises that "every person has a right to equal treatment," "freedom from harassment" advance." ${ }^{8}$ The Code also embraces the need for human rights legislation to combat systemic discrimination. ${ }^{9}$ It supports positive action to counter structural inequality by creating the duty to accommodate. It excuses "reverse discrimination" by justifying Code exceptions for affirmative action measures. It makes available to tribunals remedial powers that go beyond what courts traditionally can order.

2 "Civil rights" and "human rights" are distinct, though overlapping, concepts. In the United States, there is a longstanding "[ideological] conception that human rights was something that happened outside of the United States, and civil rights is what happened inside the United States". See Caroline Bettinger-Lopez et al, "Redefining Human Rights Lawyering Through the Lens of Critical Theory: Lessons for Pedagogy and Practice" (2011) 18 Geo J on Poverty L \& Pol'y 337 at 343-344. For the purposes of this article, the terms "human rights" and "civil rights" are used interchangeably to refer to domestic statutes that prohibit race-based discrimination.

3 Historically, race relations in Canada were framed by the dual forces of settler-indigenous and English-French dynamics. Amendments to the Immigration Act in 1967 removed significant entry barriers to people of colour, leading to Canada's emergence as the world's first officially "multicultural" state in 1971. See Joseph E. Magnet, "Multiculturalism and Collective Rights" (2005) 27 Sup Ct L Rev 431 at 440 [discussing the history of Canada's multiculturalism policy].

4 Human Rights Code, RSO 1990, c H 19 [Code].

5 Ibid, Preamble.

6 Ibid, ss 1, 2(1), 3, 4(1), 5(1), 6 (in the areas of goods, services, facilities, contracts, employment, vocational associations and housing accommodations).

$7 \mathrm{Ibid}$, ss 2(2), 5(2), 7(1), 7(2) (in the areas of accommodation and employment, including sexual harassment in those areas).

$8 \quad$ Ibid, s 7(3) (by persons in authority).

9 Rosanna L Langer, Defining Rights and Wrongs: Bureaucracy, Human Rights and Public Accountability (Vancouver: University of British Columbia Press, 2007). 
The province also established the Ontario Human Rights Commission (OHRC), a body of human rights experts to administer the Code. ${ }^{10}$ The mandate of the OHRC grew over the years and it quickly became the primary gatekeeper of the human rights system, determining which cases deserved further investigation. The OHRC also had the power to refer cases to a quasi-judicial tribunal for a determination on the merits. By 2007, however, the pressure for reform - caused mainly by overload and institutional lethargy - brought about statutory changes that removed the Commission from its gatekeeping function. ${ }^{11}$ Under the revised human rights system, in place in Ontario since June 2008, complainants may now bring cases directly to a dedicated tribunal, the Human Rights Tribunal of Ontario (HRTO), which attracts in excess of 3,000 new cases of alleged discrimination and harassment each year. ${ }^{12}$

For a long time, the most compelling critiques of human rights came from the legal left. ${ }^{13}$ Theoretical and empirical work sought to show that rights adjudication does little to dismantle structures of inequality, ${ }^{14}$ and can at times retard progress by forcing individualized claims and tying-up progressive movements in lengthy, costly and ultimately disappointing litigation. ${ }^{15}$ In the US, for instance, research on the lived impact of rights litigation led to findings that the gains of desegregation masked the emergence of new, more insidious challenges, such as racial inequality in integrated schools. ${ }^{16}$ Some argued that a controversial victory at the US Supreme Court in $R o e^{17}$ had the effect of distorting political debate on the subject of abortion and galvanizing the pro-life movement. ${ }^{18}$

Meanwhile, a vocal critique of rights also emanated from the political right. Critics voiced concern about "anti-democratic", judicially-driven rights reform efforts. ${ }^{19}$ This led defenders of rights to observe that even successful rights adjudication can have adverse consequences by producing pushback from the

10 Originally, the OHRC's mandate was to prevent discrimination through public education and policy work, as well as to investigate complaints brought under the incipient Code. It later developed a mandate to pursue complaints to a hearing.

11 See Attorney General of Ontario, Report of the Ontario Human Rights Review 2012 by Andrew Pinto (Toronto: Queens Printer for Ontario, 2012) [“Pinto Report”] at 11-19.

12 Ibid at 40.

13 See Mark Tushnet, "An Essay on Rights" (1984) 62 Tex LRev 1363; Duncan Kennedy, "The Critique of Rights in Critical Legal Studies", in Brown \& Halley, eds, Left Legalism/Left Critique (Durham, NC: Duke University Press, 2002).

14 See Nitya Duclos, "Disappearing Women: Racial Minority Women in Human Rights Cases" (1993) 6 CJWL 25 at 30 [noting that "Human rights law is not—and cannot be - a complete remedy for racism and sexism. It addresses only discrimination, which is generally understood to arise out of observable and relatively discrete acts of individuals." (emphasis added)]; Kimberle Williams Crenshaw, "Twenty Years of Critical Race Theory: Looking Back to Move Forward" (2011) 43 Conn L Rev 1253 at 1262 [rights fail to meaningfully address the "institutional, structural and ideological reproduction of racial hierarchy."']

15 See Gerald N. Rosenberg, The Hollow Hope: Can Courts Bring About Social Change? 2d ed (Chicago: University of Chicago Press, 2008).

16 See Derrick Bell, "Serving Two Masters: Integration Ideals and Client Interests in School Desegregation Litigation" (1976) 85:4 Yale LJ (arguing that remedies championed by civil rights litigation, such as integrated schools, were failing to improve the education of black children and were contrary to the wishes of many black communities that did not wish to bus their children to white schools).

17 Roe $v$ Wade, 410 US 113 (1973).

18 See Cass R Sunstein, “Three Civil Rights Fallacies" (1991) 79 Cal L Rev 751 at 766.

19 See Robert H Bork, Coercing Virtue: The Worldwide Rule Of Judges (Washington, DC: AEI Press, 2003); FL Morton and Rainer Knopff, The Charter Revolution and the Court Party (Peterborough, ON: Broadview Press, 2000). 
status quo, which in turn can have the effect of reducing the overall value of the litigation. According to this theory, these diminishing returns on rights are caused by the baggage that is brought to the progress the litigation seeks to achieve. ${ }^{20}$ As a result of these perceived risks and dilemmas, rights scholars began to lament "tragic rights" 21 and "rights gone wrong,"22 while others attempted to assemble the silver linings of "winning through losing.",23

There seems little doubt that the stated aspirations of human rights are broader and more elusive than the actual potential that statutory rights offer for promoting substantive equality. In Ontario, the goal of the Code is to create "a climate of understanding and mutual respect for the dignity and worth of each person so that each person feels a part of the community." ${ }^{24}$ Achieving that goal likely requires more than the mechanisms created by the Code can achieve beyond individual cases: it requires changes in the economic order and distribution of resources that are beyond its scope ${ }^{25}$ and changes to the dominant cultural values and social norms, which require longer term strategies. However, legal rights can perform other, often overlooked, functions. Williams describes rights as powerful rhetorical devices, leading to positive psychic and communally meaningful outcomes, such as vindication, legitimation and truth-telling with respect to discrimination and its underlying causes. Thus, both critiques of rights - of limited potential and of backlash-producing pyrrhic victories - risk exaggerating the pitfalls and obscuring the gains that rights afford. As Susan Carle writes, "Such broad conclusions lead to a state of apathy or resignation worse than a failed experiment." ${ }^{26}$

The theoretical insights of critical race studies inform two assertions that frame this article's commentary on the dilemma of false hope and the threat of backlash with respect to human rights: first, critical race theory has persuasively affirmed that affected individuals' and communities' subjective experiences with the law is an important source of knowledge that is required for a full and just application of law to facts, especially when adjudication occurs in a racialized context; ${ }^{27}$ and secondly, critical race scholars have urged a position of pragmatism when members of disadvantaged groups consider resorting to litigating rights to advance a justice claim. ${ }^{28}$ The critical race movement has continued to support the use of legal rights to advance social and political objectives, while at the same time remaining realistic about the limits of "liberal reform" within existing structures.

20 See Michael Klarman, From the Closet to the Altar: Courts, Backlash, and the Struggle for Same-Sex Marriage (New York: Oxford University Press, 2013) [Klarman, From the Closet] at 165-183.

21 Robin West, "Tragic Rights: The Rights Critique in the Age of Obama" (2011) 53 Wm \& Mary L Rev 713.

22 Richard Thompson Ford, Rights Gone Wrong: How Law Corrupts the Struggle for Equality (New York: Farrar, Straus and Giroux, 2011).

23 Douglas NeJaime, "Winning Through Losing” (2010) 96 Iowa L Rev 941.

24 Code, supra note 4, Preamble.

25 See Thompson Ford, supra note 22 at 143 [arguing that courts erred in defining racial equality under civil rights statutes as the elimination of dignitary harm, like "stigmatic injury, stereotypes and subjective emotional harm," rather than focusing on "economic justice and the tangible evils of the American racial hierarchy."]

26 Susan D Carle, "How Myth-Busting About the Historical Goals of Civil Rights Activism Can Illuminate Future Paths" (2011) 7 Stan J Civ Rts \& Civ Liberties 167 at 194.

27 See Williams, supra note 1 at 220.

28 Richard Delgado, "The Ethereal Scholar: Does Critical Legal Studies Have What Minorities Want" (1987) 22 Harv CRCLL Rev 301 at 304-306 [describing the importance of structured rights for society's most disadvantaged members who otherwise wield little to no power]. 
This article explores these themes in the light of the judgment of the Ontario Court of Appeal in Peel Law Association v. Pieters. ${ }^{29}$ In that case, a unanimous court endorsed a contextually nuanced treatment of evidence by the HRTO. The tribunal decision named anti-black racism as a social distortion that unconsciously affects individual behaviour and seeps into actions that may appear to be nondiscriminatory but which are experienced as discrimination by those affected. This "fact" of unconscious bias formed the basis for the adjudicator to infer a racial motive on the part of the perpetrator, despite the absence of traditional, "hard" evidence. Pieters and related cases illustrate how unconscious racial bias has been accepted as a basis for determining issues of liability for discrimination under statutory human rights. These cases build on two decades of criminal law jurisprudence recognizing unconscious bias as a factor at play in law enforcement.

This article also considers the rise of human rights scepticism as a counterweight to the assumption that society follows the lead of the law when it comes to recognizing rights. By exploring select doctrinal developments and public commentary, this article suggests that, rather than being cause for alarm and retreat of the rights agenda, what is characterized as "backlash" may in fact be part of a longer process of attitude and norm shifting. In the final analysis, the article returns to Williams' account of legal rights offering "islands of empowerment" amid conditions of pervasive racial disadvantage. It concludes that maintaining a pragmatic commitment to rights allows for the instrumental use of litigation, tempered by a critical view of underlying social conditions that structurally impede the capacity of the law to fully realize the goal of racial emancipation. ${ }^{30}$

\section{THE CASE OF THE BLACK LAWYERS}

One day in May 2008, Selwyn Pieters, a dreadlocked, black lawyer, and his two black, male colleagues appeared in a Brampton, Ontario courthouse. While taking a break in the lawyers' lounge, operated by the Peel Law Association, they were approached hastily by the courthouse librarian. The rules of the lounge provided that only lawyers and law students were permitted to use the lounge. Interrupting Pieters, who was on the phone, the librarian demanded to see proof that he and his colleagues were entitled to be in the lounge. She told him that "paralegals" are not allowed. There were about 20 people in the lounge at the time, but the white librarian asked only the three black men to produce identification to establish that they were lawyers. ${ }^{31}$ Pieters accused the librarian of racial profiling.

Pieters, along with one of his associates, Brian Noble, commenced a proceeding under the Code alleging discrimination in the provision of services, goods and facilities by the Association. The men claimed that their race and colour was a factor in the librarian's decision to approach and question them in the manner that she did. They believed they had been racially profiled. The case went to a hearing before the HRTO, where several witnesses testified as to what occurred that day. While their stories

292013 ONCA 396 (CanLII) [Pieters], rev'g 2012 ONSC 1048 (CanLII) (Div Ct) [Pieters, Div Ct], aff'g 2010 HRTO 2411 (CanLII) [Pieters, HRTO].

30 In the interest of clarity, my use of the phrase "racial emancipation" can be defined as the process of liberation from legal, social or political burdens or exclusions based on race, ethnicity or colour amid conditions of white privilege.

31 Pieters, HRTO, supra note 29 at paras 5-16. These facts were found by the Tribunal and accepted on appeal. 
were far from concordant, the HRTO assessed credibility and pieced together the most likely account of the facts. ${ }^{32}$

The adjudicator accepted that the librarian had entered the lounge without any intention to check identities, but that, upon noticing the men, decided spontaneously to approach them. The mindset of the librarian was key to the HRTO's factual findings and determinative of the ultimate legal conclusions. Why did she approach these men, and only these men? From the perspective of the black men, it was abundantly clear: she was motivated, consciously or unconsciously, by anti-black stereotypes. The men testified that in their daily lives they routinely faced the assumption that black men are not likely to be lawyers, and that they cannot be trusted. The librarian testified that the only reason she asked the men for identification was because she did not recognize them personally — not because of an assumption about their race.

The HRTO accepted that the librarian "regularly asked persons to confirm whether they were lawyers, articling students or students of law in order to determine whether they were admissible to the lounge and library." ${ }^{, 33}$ The adjudicator also accepted that there were other individuals in the lounge at that time who were not black and who the librarian did not personally know. ${ }^{34}$ The evidence was that she focused her attention on the black men and not on the others. This fact, and the absence of a plausible alternative explanation, led the adjudicator to infer the conclusion that the men's race had been a factor in attracting the librarian's attention. ${ }^{35}$

While the HRTO found the librarian lacked credibility in explaining why she focused her attention on the black men, the adjudicator accepted the librarian's testimony that when she was confronted with the accusation of racial profiling, she was hurt and visibly shaken:

I accept the personal respondent's testimony that the allegation that she was racially profiling the applicants shook her and that it affected her subsequent actions. Her testimony about the numbing effect it had on her, that she felt overwhelmed, and that she determined that she had to focus her attention specifically on Mr. Pieters, was emotional, detailed, forthright, and persuasive on this point. ${ }^{36}$

The librarian was sincerely hurt by the accusation that she was racially profiling the black lawyers. For an accusation to sting, one might think it must have some air of subjective truth. A truly ludicrous accusation would simply be dismissed and corrected. But, then again, some accusations are so serious that they are received as an attack and they can cause emotional injury, even if the accusation is untrue; perhaps especially if the accusation is untrue. Indeed, the manifest sincerity of the librarian's shock might reveal that she could not possibly have harboured any bias towards the black lawyers. On the other hand, it might illustrate that the bias was present but was so embedded in her unconscious mind that it was completely unknown to her. The latter is what the HRTO concluded: despite the librarian's sincere ignorance of her own racial bias, the evidence supported the inference that she was influenced, at least in part, by unconscious racism.

\footnotetext{
Ibid at para 4.

Ibid at para 30.

Ibid at paras 79-80.

Ibid at para 84 .

Ibid at para 78.
} 


\section{UNCONSCIOUS RACISM: NAMING THE INVISIBLE (BUT HEAVY) HAND ${ }^{37}$}

Critical race scholars have long described and theorized the experience of racial discrimination at the hands of unwitting perpetrators. Recounting "ordinary", every-day incidences of racism, such accounts do not involve slurs or explicit exclusions of the sort that gave rise to the human rights imperative in the first place. Today, racism operates mostly invisibly in societies like Canada, where overt racial discrimination earns widespread public opprobrium and public values of tolerance are widely expressed. However, for those like Pieters and Williams, who implicitly understand when their race affects how others treat them, unconscious bias is present and influential in society. It leads to behaviour that exhibits or produces racial discrimination, which can have a meaningfully adverse impact on individuals and communities. ${ }^{38}$ Concerning the intention or mindset, the person exhibiting the discriminatory behaviour does not necessarily need to plan or desire to cause a racially adverse outcome. But at the same time, the discriminatory outcome is not detached from the values, priorities and assumptions of the person exhibiting the behaviour. Thus, while the bias is not present in the mind of the individual, it is embedded within the person. Unconscious racial bias "is rooted in unstated assumptions and values and can influence one's "beliefs about race or the occasions on which those beliefs affect our actions... . [A] large part of the behavior that produces racial discrimination is influenced by unconscious racial motivation." 39

The most evident illustration of unconscious racial bias can be found in the context of racially disparate law enforcement practices. ${ }^{40}$ According to Stribopoulos, the moment of decision, when police exercise their discretion to arrest, is when minorities are most vulnerable to racial discrimination:

No doubt some police officers hold overtly racist views that may lead them to abuse their arrest powers. Much more likely, however, is the risk that many more police officers subconsciously operate on the basis of stereotypical assumptions regarding visible minorities. An officer's assessment of her or his grounds for an arrest may be partially skewed by a belief that certain visible minorities are more likely to commit crimes. ${ }^{41}$

37 This very loose appropriation of the economics metaphor of an ever-present, but invisible, self-regulating force exerted in the behaviour of markets captures the contested notion that racism in whatever form it takes can maximize its object (discrimination, not wealth) if left unchecked by government intervention. See Adam Smith, The Wealth of Nations (London: W Strahan and T Cadell, 1776).

38 See Williams, supra note 1 at 44-51 [describing being excluded from a Benetton store while Christmas shopping, and subsequently writing about it despite her editors' refusal to see race as an issue: "All reference to my race had been eliminated because it was against 'editorial policy' to permit descriptions of physiognomy .... In a telephone conversation to them, I ranted wildly about the significance of such an omission. 'It's irrelevant,' another editor explained .... 'It's nice and poetic,' but it doesn't 'advance the discussion of any principle .... This is a law review, after all.'”]

39 Charles R Lawrence III, “The Id, the Ego, and Equal Protection: Reckoning with Unconscious Racism” (1987) 39 Stan L Rev 317 at 322.

40 See David Tanovich, “Moving Beyond 'Driving While Black:' Race, Suspect Description and Selection” (2004 - 2005) 36 Ottawa L Rev 315 at 320 (Noting the pervasiveness of overt and unconscious bias in policing: "We need to ask ourselves whether we are satisfied that the remnants of overt racism are no longer present. We also need to be cognizant of systemic or unintentional racism.")

41 James Stribopoulos, "Unchecked Power: The Constitutional Regulation of Arrest Reconsidered" (2003) 48 McGill LJ 225 at 250 . 
In Nassiah v. Peel Regional Police, ${ }^{42}$ a case decided by the HRTO three years prior to Pieters, the HRTO recognized the prevalence of police bias, and situated it within the broader social context. The tribunal decision, which was never reviewed by a superior court, heavily coloured the Court of Appeal's treatment of the facts in Pieters. The facts of Nassiah stemmed from an incident in which the police were called to apprehend a suspected shoplifter at a large department store in Mississauga, a diverse suburban hub near Toronto. ${ }^{43}$ The suspect, a black woman who spoke foreign-accented English, had been wrongly suspected of theft by store security. Despite the woman's insistent denials and no proof that she had stolen anything, the police pursued an investigation on the basis of the unfounded suspicion of the white security officer. The HRTO found that the white male police officer began his investigation with discriminatory assumptions: that the black suspect might not speak English, that she was not truthful and that she was guilty. ${ }^{44}$ The officer's behaviour in conducting the search also betrayed his discriminatory mindset. He ignored videotape evidence exonerating the suspect and ordered two body searches that yielded nothing but humiliation for the victimized woman.

That the investigation was excessive and ill-conceived was clear on the facts. That the item the woman was accused of stealing was worth less than $\$ 10$ made the police officer's relentless pursuit appear to be more than over-zealous law enforcement; his disregard for evidence more than incompetence. Looking behind the officer's stated motives and actions, the adjudicator relied on expert evidence to accept as fact that, "statistically, racial minorities, particularly Black persons, are subject to a higher level of suspicion by police because of race, often coupled with other factors." 45 The HRTO went on to describe three causes of racial profiling: overt racism, meaning that some officers will deliberately single out racial minorities and treat them more harshly; efficiency, by which police use information about crime prevalence and certain minority groups to target members of those groups; and, finally, unconscious bias. ${ }^{46}$ Explaining this last source of racial profiling, the adjudicator concluded that "police officers, like all members of society, develop unconscious stereotypes about racial groups and subconsciously act on those stereotypes during routine police investigations."47

42 Nassiah v Peel (Regional Municipality) Services Board, 2007 HRTO 14 (CanLII) [Nassiah].

43 Nearly half of the population of the city of Mississauga is non-white, and nearly half do not speak English as a first language. See Statistics Canada, Focus on Geography Series, 2011 Census: Census Subdivision of Mississauga, CYOntario (Ottawa: StatCan, 2012), online: $<$ http://www12.statcan.ca/census-recensement/2011/as-sa/fogs-spg/Facts-csdeng.cfm?LANG $=$ Eng $\& G K=C S D \& G C=3521005>($ In $2011,47.6 \%$ of the population reported English as mother tongue, $47.0 \%$ reported a non-official language. In 2006, the ethnic breakdown was an even 50/50 split between whites and nonwhites).

44 Nassiah, supra note 42 at paras $75,85$.

45 Ibid at para 126.

$46 \quad$ Ibid at paras 127-128.

47 Ibid at para 129 (emphasis added). 


\section{IV. "WE ARE ALL RACISTS"48}

In Pieters, the HRTO referred to the findings in Nassiah, the suspected shoplifting case, to infer in the absence of a plausible explanation from the librarian that she, like "police officers" and "all members of society," was acting on "unconscious stereotypes about racial groups."49 The Association disagreed and sought judicial review of the HRTO's decision in Divisional Court. It argued that there had been no actual evidence of discrimination for the HRTO to reach its conclusion and that the adjudicator had applied an incorrect test that put the librarian in the position of having to explain how her neutral behaviour was not racist. ${ }^{50}$ The reviewing court agreed with the Association and found that by "improperly reversing the burden of proof, the Tribunal placed her in the difficult position of trying to prove a negative, namely, that her conduct in the performance of her routine duties was not motivated by race and colour." ${ }^{51}$ The Court went on to reason that the adjudicator had erred in relying on Nassiah to infer a nexus between the black lawyers' race and their treatment by the librarian. ${ }^{52}$ The court held that the difference between a librarian's routine duties and those of a police officer are too "significant" to warrant drawing parallels. ${ }^{53}$

At the Court of Appeal, the Association argued not only that the facts of Nassiah were distinguishable, but additionally that it was improper as a matter of law for the HRTO to rely on any expert evidence that was not called in the instant case. The Court agreed that the HRTO must be careful when considering evidence that is not directly before the trier of fact but that the "resort to Nassiah was of no material consequence to [the] decision." ${ }^{\text {"54 }}$ The Court focused on the purpose for which the evidence was canvassed. The Court began by stating that the adjudicator had actually drawn two inferences about the librarian's conduct. First, the adjudicator found (without resort to the Nassiah evidence) that race had been one of the factors that had influenced the librarian to question the men in the first place. Only after drawing this inference from the evidence it heard, the adjudicator turned to the Nassiah expert evidence to highlight that race is often not only a factor in a decision to investigate, but also a factor in the manner of investigation. This evidence lent support to the HRTO's second inference that the "the way in which [the librarian] interacted with the applicants was tainted by consideration of their race and colour. ${ }^{, 55}$ The Court held that the first inference addressed the main issue in the case: that

48 Lawrence, supra note 39 at 322 [emphasis added]:

[We Americans] share a common historical and cultural heritage in which racism has played and still plays a dominant role. Because of this shared experience, we also inevitably share many ideas, attitudes, and beliefs that attach significance to an individual's race and induce negative feelings and opinions about nonwhites. To the extent that this cultural belief system has influenced all of us, we are all racists. At the same time, most of us are unaware of our racism.

49 Nassiah, supra note 42 at para 129. See also Pieters, HRTO, supra note 29 at para 91.

50 Pieters, Div Ct, supra note 29 at paras 34-35.

$51 \quad$ Ibid at para 37.

52 Ibid at para 43. Justice Chapnik opined: While police have authority, power and control over citizens, Ms. Firth is a librarian, employed to provide library services to lawyers, and she had no legal authority or power to detain, pursue or investigate the complainants. I agree with the applicants that the reliance by the Vice-Chair on law enforcement cases was misconceived.

53 Ibid at para 41.

54 Pieters, supra note 29 at para 124.

$55 \quad$ Ibid at para 119. 
is, whether the decision to stop and question the black lawyers was discriminatory. The "aggressive" manner in which the librarian questioned the lawyers was a secondary issue of discrimination that simply confirmed the primary discriminatory action.

The Court went on to accept as a "sociological fact" that "racial stereotyping will usually be the result of subtle unconscious beliefs, biases and prejudices." ${ }^{, 56}$ This offered further context for drawing the inference of bias, bolstering the reasonableness of the HRTO's finding. The Court cited Justice Doherty's description of unconscious bias in $R v$. Parks: "Racism, and in particular anti-black racism, is a part of our community's psyche. A significant segment of our community holds overtly racist views. A much larger segment subconsciously operates on the basis of negative racial stereotypes." ${ }^{57}$ The Court also noted the adoption of this passage by the Supreme Court of Canada in $R$ v. S.(R.D.). ${ }^{58}$ In that case, the highest court upheld the reasoning of a black Nova Scotian trial judge, whose characterization of anti-black racism as "the prevalent attitude of the day" led her to doubt the credibility of a white police officer accused of racially profiling a young black male. ${ }^{59}$

Thus, on the one hand, the law recognizes that a large number of Canadians operate on the basis of racial stereotypes. However, proving such behaviour "objectively" in specific circumstances, and in the absence of explicit admissions, remains a challenge. Williams describes this tension between the objectivity of the law and the truths about minorities' experiences with racial bias as a primary source of the law's alienating tendencies. We can see that, when the law privileges an "objectivist" theory of truth, it necessarily mutes powerful subjective experiences with discriminatory impact. ${ }^{60}$ This highlights an "implicit contrast between those whose self-believed stories are officially approved, accepted, transformed into fact, and those whose self-believed stories are officially distrusted, rejected, found to be untrue, or perhaps not heard at all." ${ }^{, 61}$ The rigidity in traditional legal methodology "destabilizes the very stability that ought to inhere in [the conventional] disciplining and methodical approach to textual analysis and legal methodology." "62 By destabilizing conventional legal methodology, one can see openings for alternative, and more broadly truthful, renderings of the facts in human rights litigation.

To this end, Williams urges us to re-think "truth" and "facts" as "rhetorical gestures", in order to shift what is considered normal and natural within law's purview. ${ }^{63}$ Doing this can highlight the normative biases and blind spots that underlie traditional approaches to legal truth and knowledge. It also exposes the asymmetrical social and economic structures that formally limit the ability of legal process to account for all of the relevant considerations when race is an issue and that create distortions in fact-

56 Ibid at paras 111-113.

57 Ibid at para 113, citing $R v$ Parks (1993), 15 OR (3d) 324 at para 54, 84 CCC (3d) 353 (CA).

58 Pieters, supra note 29 at para 114, citing $R v S(R D)$, [1997] 3 SCR 484 at para 46 [RDS], 151 DLR (4th) 193.

59 RDS, ibid at para 4. The question was whether the trial judge reached her decision fairly, resting her ruling on the evidence or on "something else" (ibid at para 3).

60 Kim Lane Scheppele, "Foreword: Telling Stories" (1989) 87 Mich L Rev 2073 at 2088-2089 [“The objectivist theory of truth holds that there is a single neutral description of each event which has a privileged position over all other accounts. This single, neutral description is privileged because it is objective, and it is objective because it is not skewed by any particular point of view.]

61 Ibid at 2089.

62 Reginald Leamon Robinson, "Race, Myth and Narrative in the Social Construction of the Black Self" (1996) 40 How LJ 1 at 122 .

63 Williams, supra note 1 at 10. 
finding. For Williams, changing "objective truth" into a rhetorical move disrupts established frames that exclude minorities' realities, and enables "a more nuanced sense of legal and social responsibility." This enhances the pursuit of a clearer truth "because much of what is spoken in so-called objective unmediated voices is in fact mired in hidden subjectivities and unexamined claims...." accept that objective truth in the context of the law's structuring of interests is rooted in non-universal subjectivities that are rarely questioned, then the goal of making law both more inclusive and more aligned with reality requires integrating additional subjectivities into its forms and practices.

For some, this might be seen to create problems of indeterminate claims, unverifiable evidence and unpredictability in legal outcomes, and attendant concerns about procedural fairness. If most Canadians harbouring bias act unconsciously on racial stereotypes, the task of identifying the facts will be most important in discrimination litigation, and will often depend on interpreting between the lines. "Who did what, to whom, and why?" are the critical questions. This also raises practical challenges. How should employers, public officials and everyday people be expected to comply with the prohibition on discrimination if their behaviours can be dictated unwittingly by bias? In this reality, virtually anyone could be accused of racial discrimination; what is more, one cannot eliminate the risk because no one can know for certain whether one is infected with racial bias or how it will manifest. In the wake of Pieters, the Peel County Law Association may be in no better position of knowing how to manage its risk of human rights litigation than it was before the incident giving rise to the case. How does this advance the cause of social transformation and racial justice?

In the result, the courts and tribunals are left to decide on a case-by-case basis. If an allegation of discrimination is upheld, the respondent is "outed" and their unconscious bias is confirmed and declared for all to see. If the claim is denied, the respondent has attracted stigma and expended considerable energy and resources defending their name, and neither they, society, nor the aggrieved person is any better off. In effect, when unconscious racism is identified and upheld at adjudication, the decision will often speak more to general truths than to a particular truth, yet the remedies do little to address underlying causes. Such decisions, if taken seriously, do imply collective guilt, and point the finger at members of non-racialized communities to confront and assume responsibility for their own unconscious prejudices. ${ }^{66}$ Taking responsibility for eradicating the underlying causes of racial discrimination begins with this shared mea culpa.

\section{TRANSFORMATION AND BACKLASH}

In $R D S$, the Supreme Court split 6-3 on the question of racial bias. That case arose after a 15 year-old black male was charged with interfering in the arrest of his friend and assaulting a police officer. The officer and the boy told very different versions of the story. The trial judge, a black woman, acquitted the boy after failing to be persuaded by the officer. She found that "police officers have been known to

Ibid at 11.

Ibid.

66 This phenomenon has, at times, been referred to as "reverse stereotyping." See e.g. Monica Biernat, "Toward a Broader View of Social Stereotyping" (2003) 58:12 American Psychologist 1019. 
[mislead the court] in the past" and that "police officers do overreact, particularly when they are dealing with non-white groups." ${ }^{.67}$

For members of racial minority groups across the country - especially African Canadians - the RDS decision was a key moment of judicial truth-telling. The black trial judge's approach to race and policing engaged differently with the law's aspiration to "blind justice." Her judgment introduced the black experience into the background facts of legal decision-making. In this respect, the trial judge was phenomenological in her approach to fact finding. ${ }^{68}$ She heard the evidence - the "he said, she said" and moved between what was stated and what was not, and between the subjective and the objective, to unearth a different form of truth from what the law normally recognizes. This truth was constructed not only by the evidence adduced, but also by the judge's experience with the evidence and with the world. Rather than viewing this as corrupting the trier of fact's judgment, the trial judge's phenomenological approach was ultimately vindicated at the Supreme Court of Canada. ${ }^{69}$

While a majority of the Court accepted the trial judge's approach to hearing the evidence and deciding the racial question, the minority concluded that it was the trial judge, not the police officer, who was drawing racial assumptions. Justice Major (joined by Lamer C.J. and Sopinka J. in dissent) chastised the judge for "stereotyping all police officers as liars and racists" and for improperly applying "this stereotype to the police officer in the present case.... ."70 The dissent concluded as follows:

Whether racism exists in our society is not the issue. The issue is whether there was evidence before the court upon which to base a finding that this particular police officer's actions were motivated by racism. There was no evidence of this presented at the trial. ${ }^{71}$

The deep split at the Supreme Court of Canada in $R D S$ epitomizes the problem of identifying the manifestations of racial discrimination within an adjudication framework. How the facts will be established depends on the normative lens applied by the trier of fact. If the trier of fact accepts that racism exists, is pervasive and embedded in society, this will lead to a different interpretation of evidence than if the trier of fact begins from an assumption of race-neutral social conditions. While most may agree that racism exists in society, how racism manifests, when and by whom, is deeply contested. Important judicial pronouncements, sometimes in majority and sometimes in dissent, are paying heed to the emanating effects of historical, deeply socialized and institutionalized forms of racism that continue to infect social relations and lead to individual acts of discrimination. ${ }^{72}$ In a recent case before Ontario's Law Society Appeal Tribunal involving the disbarment of a black lawyer for professional misconduct,

$67 \quad R D S$, supra note 58 at para 5.

68 See Peter Gabel, "The Phenomenology of Rights-Consciousness and the Pact of the Withdrawn Selves" (1984) 62 Tex L Rev 1563 at 1563-1564 [Defining the phenomenological method as the "effort to critically reexperience the phenomena of everyday life with an eye to illuminating their hidden meanings... its value for showing how law is 'constitutive' of our social experience becomes apparent the moment we try to grasp what 'the law' actually is."] For the phenomenology of judging, see also Duncan Kennedy, "Freedom and Constraint in Adjudication: A Critical Phenomenology" (1986) 36 J Legal Educ 518.

69 RDS, supra note 58.

70 RDS, supra note 58 at para 6.

71 Ibid [emphasis in the original]. 
the panel of benchers split 3 to 2 over whether the effects of systemic racism should substantially mitigate the penalty. The majority extended a touch of clemency and allowed the lawyer to relinquish his licence rather than be disbarred. The two dissenters would have given him a second chance. Their dissent made ample reference to the history and impact of racism in the legal profession:

\begin{abstract}
The research into Canadian legal history shows that systemic racism has had a substantial impact on the legal profession... Those who succeeded in obtaining entry found that those barriers continued to impact upon their careers when they attempted to practise. Significantly, an increased risk of disbarment was one such barrier for racialized lawyers.

It would be misguided to be aware of this history and yet ignore its contemporary incarnations simply because the legal profession has today become much more diverse. The legal profession has made no concerted effort to rid itself of the racism inherent in the practice. As the evidence in this case illustrates, racialized lawyers continue to face barriers not experienced by their colleagues. ${ }^{73}$
\end{abstract}

It is notable that courts and tribunals are slowly but surely picking up the threads of $R D S$ and have begun to stitch a jurisprudence that accounts for diverse subjective perspectives that are usually dismissed as irrelevant or unsubstantiated by conventional legal process. Racialized persons subjectively know, and implicitly understand, when they are experiencing the effects of bias. ${ }^{74}$ Yet, there is rarely a "gotcha" moment: direct evidence confirming the racialized person's experience with discrimination is not self-revealing. It must be extracted, inferred and assembled. Closets must be emptied.

Not surprisingly, when a person alleges racial discrimination, the named offender feels accused of a terrible wrong. The accusation cuts deeper than other comparable forms of legal action. The label "alleged racist" carries a stigma that delivers a more stinging bite than a law suit for breach of contract or negligence. The accusation of discrimination itself has come to be seen as a form of smear and insult. What is worse is that the respondent will continue to feel misunderstood, genuinely failing to see the discriminatory conduct. This was evidenced in the librarian's testimony in the Pieters case and in the Association's strident defence of her motives, behaviour and character. According to one intervener: "Few claims can bring greater public opprobrium than being labelled a racist or found to have discriminated against a member of a protected group. ${ }^{.75}$

Beyond the insult and stigma, critics also argue that the ease of access for complainants and flexible procedures at tribunals have created unfairness to respondents, holding them hostage to a skewed

72 Lawrence, supra note 39 at 330 (describing racism in diagnostic terms as an "illness," arguing that "[w]e must understand that our entire culture is afflicted, and we must take cognizance of psychological theory in order to frame a legal theory that can address that affliction.").

73 Law Society of Upper Canada v McSween (2012) ONLSAP 3 (CanLII) at paras $72-73$ [dissenting decision of Clayton Ruby and Constance Backhouse].

74 See, e.g., Frances Henry, The Caribbean Diaspora in Toronto: Learning to Live with Racism (Toronto: University of Toronto Press, 1994) [describing the process by which people of Caribbean origin are "differentially incorporated" into Canadian society and whose experience as Canadian is shaped in some way or another by racism]

75 Pieters, supra note 29 (Factum of the Intervener The League for Human Rights of B'nai Brith Canada) [on file with author] at para 24 [League factum]. 
process. $^{76}$ Such critics have at times described Commission investigations as fishing expeditions ${ }^{77}$ and tribunal hearings as "kangaroo courts." 78 Certainly, the statutory systems that handle complaints of discrimination have been designed with an explicit access to justice mandate and subject matter expertise. Rather than burdening generalist courts with highly contextual, fact-driven trials to identify discrimination, the Supreme Court of Canada decided more than 30 years ago that there is no tort of discrimination justiciable in the courts. ${ }^{79}$ Legislatures across the country have overwhelmingly embraced statutory human rights and administrative procedures as the preferred manner for managing claims of discrimination. ${ }^{80}$

Yet, while one may consider specialized tribunals with expert members trained in human rights investigation and analysis to be an institutional strength, there has been a considerable effort to discredit human rights institutions. ${ }^{81}$ Resistance to civil rights statutes is neither new nor unique to Ontario. In the wake of the US Supreme Court's desegregation decision in Brown v. Board of Education, ${ }^{82}$ and subsequent legal action by the NAACP to enforce compliance, the State of Virginia went so far as to

76 Infamously, Ezra Levant taped and posted online his "interrogation" by an Alberta Human Rights Commission investigator in a complaint related to his publishing of the Danish "Muhammad" cartoons in the Western Standard newspaper.

77 Joseph Brean, “No basis' for B'nai Brith hate charge”, National Post (12 March 2009) online:

$<\mathrm{http}$ //databank.isranet.org/article.asp?article=46966> (quoting lawyer David Matas, senior counsel to B'nai Brith, describing a Manitoba Human Rights Commission investigation into a complaint that the organization sponsored a conference promoting racial profiling against Muslims).

78 Editorial, "You call this 'human rights'?" National Post (7 February 2011) A8 [Post Editorial, "You call this"] . The editorial argues:

Those who cry racism (or some other -ism) have their legal fees covered by taxpayers, while defendants must pay their own costs. Commissions do not follow the usual laws of evidence. They give complainants wide latitude to prove their cases -- including sometimes even allowing hearsay evidence -- while hamstringing defendants... . $[\mathrm{H}]$ earings often resemble kangaroo courts rather than judicial proceedings, even though their outcomes have the force of law in most provinces... . It's an institutionalized bonanza for anyone who carries a grudge against his or her boss or landlord.

79 Seneca College v Bhadauria, [1981] 2 SCR 181 (CanLII).

80 See Code, supra note 4; Alberta Human Rights Act, RSA 2000, c A-25.5; Human Rights Code, RSBC 1996, c 210; The Saskatchewan Human Rights Code, SS 1979, c S-24.1; The Human Rights Code, CCSM c H175; Charter of human rights and freedoms, CQLR c C-12; Human Rights Act, RSNB 2011, c 171; Human Rights Act, RSNS 1989, c 214; Human Rights Act, RSPEI 1988, c H-12; Human Rights Act, 2010, SNL 2010, c H-13.1; Human Rights Act, RSY 2002, c 116; Human Rights Act, SNWT 2002, c 18; Human Rights Act, SNu 2003, c 12. In July 2011, amendments to The Saskatchewan Human Rights Code eliminated the Saskatchewan Human Rights Tribunal and transferred its powers to the Saskatchewan Court of Queen's Bench. See the Saskatchewan Human Rights Code Amendment Act, 2010, SS 2011, c 17.

81 See e.g. Jonathan Kay, "Human rights commissions have had their day", National Post (6 March 2013), online: $<$ http://fullcomment.nationalpost.com/2013/03/06/jonathan-kay-human-rights-commissions-have-had-their-day/>; "National Post editorial board: Real court tells Human Rights Tribunal who's boss", National Post (15 February 2012), online: <http://fullcomment.nationalpost.com/2012/02/15/national-post-editorial-board-real-court-tells-human-rightstribunal-whos-boss/> ["National Post editorial board: Real court"]; Jonathan Kay, "Windsor Law School's Carasco fiasco: A case study in the need to rein in human rights commissions", National Post (29 September 2010), online: $<$ http://fullcomment.nationalpost.com/2010/09/29/windsor-law-schools-carasco-fiasco-a-case-study-in-the-need-to-reinin-human-rights-commissions/>. See also infra notes $91,101$.

82347 US 483 (1954) [Brown]. 
pass a law to suppress civil rights litigation. ${ }^{83}$ Although that law was eventually struck down by the US Supreme Court, ${ }^{84}$ the climate of hostility to litigating civil rights never seriously abated. ${ }^{85}$

In the United States, scholars have noted that "backlash" to strong rights enforcement can generate stiff resistance from centres of power. ${ }^{86}$ The more the enforcement of the right affects elite, majoritarian or material interests, the more likely it is to produce resistance. The argument in the case of racial equality and desegregation is that aggressive civil rights litigation has actually stunted progress towards greater social equality by virtue of entrenching conservative white opinion against a perceived threat of black empowerment through law. ${ }^{87}$ This theory holds that the emphasis in discrimination law on dignitary rather than material interests has obscured issues of economic injustice by focusing entirely on "stigmatic injury, stereotypes and subjective emotional harm." 88 This has led to the amplification of "trivial" distinctions that have distracted from more critical and emerging questions of social justice. ${ }^{89}$ These distortions, produced by campaigns intended to remedy inequality, have in fact been more beneficial to whites than blacks. ${ }^{90}$ Thus, at times when law appears to be delivering success to those concerned with racial justice, the exact opposite may be underway.

\section{FREE SPEECH AND HUMAN RIGHTS SCEPTICISM}

In Canada, political backlash to human rights, in particular on the issues of hate speech regulation and religious accommodation, surged in the mid to late $2000 \mathrm{~s}$, and produced spirited public debate. ${ }^{91}$ The backlash manifested as scepticism of human rights institutions and enforcement. At the centre of the

83 Chapter 33 of the Virginia Acts of Assembly, Extra Sess 1956, amended numerous statutes to broaden the definitions of barratry, champerty and maintenance so as to ban the "improper solicitation of any legal or professional business."

84 Harrison v NAACP, 360 US 167 (1959); NAACP v Button, 371 US 415 (1963).

85 Thompson Ford, supra note 22.

86 See Klarman, From the Closet, supra note 20 at 165-183 (examining judgments in "cause" cases "that seem to retard the causes they purport to benefit while sometimes also producing larger political consequences").

87 Michael Klarman, "Brown and Lawrence (and Goodridge)" (2005) 104 Michigan L Rev 431.

88 Thompson Ford, supra note 22 at 143.

89 Samuel R Bagenstos, "The Structural Turn and the Limits of Antidiscrimination Law" (2006) 94 Cal L Rev 1 at 3 (arguing that "unconscious bias, interacting with today's 'boundaryless workplace,' generates inequalities that our current antidiscrimination law is not well equipped to solve [and that] [t]here is little reason to believe that a structural approach to employment discrimination law will actually be successful.”).

90 Derrick Bell, Jr, "Diversity’s Distractions" (2003) 103 Colum L Rev 1622 at 1633 (arguing that any measure advancing racial equality, such as affirmative action, will only be successful if it is in white people's interests and not perceived to be benefitting blacks at the expense of whites).

91 See e.g. Ingrid Peritz, “Gym, Jews Don't See Eye to Eye: Y's Workout warriors protest frosted glass installed at behest of synagogue members", The Globe and Mail (8 November 2006) A1 (regarding a dispute between some members of a Montreal YMCA and a neighbouring Jewish synagogue after the YMCA installed frosted windows in the exercise room to block congregants and children from viewing women exercising); Kirk Makin, "Ontario Court Rejects Religious Exemption to Motorcycle Helmet Law", The Globe and Mail (6 March 2008) (regarding a Sikh man who unsuccessfully challenged mandatory helmet legislation in Ontario). Controversy surrounding minority accommodation led to the creation of a Royal Commission in Quebec to investigate the issue of cultural accommodation in the province. See Building the Future: A Time for Reconciliation, Abridged Report of the Consultation Commission on Accommodation Practices Related to Cultural Differences (English)by Gerard Bouchard \& Charles Taylor (Quebec City: Government of Quebec, 2008). 
controversy was the 2006 publication of excerpts from America Alone, ${ }^{92}$ a polemic by right-wing pundit Mark Steyn, in the newsmagazine Maclean's. The book's general theory was that "Islam" (i.e., Muslim people) posed an existential threat to Europe. Steyn forecasted that Muslims would become a "successor population" due to the combination of immigration and high birth rates among European Muslims. In the result, America would have to fend for itself in a hostile, illiberal world.

Unsurprisingly, Steyn's book outraged many Muslims, who criticized it for reproducing stereotypes and generating unfounded fear. They accused Maclean's of lending legitimacy and public profile in the pages of Canada's only national newsmagazine to views described as intolerant and xenophobic. ${ }^{93}$ Human rights cases against the publisher were filed in three different jurisdictions, apparently in synchrony, in British Columbia, Ontario and at the federal level. ${ }^{94}$ Public coverage of the cases focused almost entirely on the free speech defence raised by the respondent, Maclean's, rather than on the accusation that the newsmagazine had engaged in the prohibited conduct of promoting hate. Newspapers, including publications known for cultural inclusiveness like the Toronto Star, called for reforms to the human rights system lest a chill take hold on freedom of expression. The purpose of the Code, according to the Star's editor, was to curb "bigoted acts," not to constrain press freedoms. ${ }^{95}$

None of the litigation was successful. ${ }^{96}$ The Ontario Human Rights Commission (OHRC) decided that the matter was not within its jurisdiction, then proceeded to issue a written admonishment to Maclean's in which it recognized the importance of a free press, but expressed concern about the media's promotion of societal intolerance towards Muslim, Arab and South Asian Canadians. ${ }^{97}$ The federal Canadian Human Rights Commission dismissed the complaint on June 26, 2008, without referring it to a tribunal for a hearing. ${ }^{98}$ The British Columbia Human Rights Tribunal, which receives complaints directly, conducted a hearing in June 2008 and dismissed the case on the merits in a decision dated October 10, 2008..$^{99}$

For the critics, the mere fact that human rights bodies had the power to haul writers and publishers before adjudicators and commissions to "try" them for their ideas was not only unfair, but also a denigration of the freedoms integral to Canadian democracy. In particular, the right to free speech was largely posited as the ultimate "victim" of these discrimination claims. Human rights scepticism viewed commissions and tribunals with suspicion, casting them as ominous, Big-Brother agencies that threaten

92 Mark Steyn, America Alone: The End of the World as We Know It (Washington, DC: Regnery, 2006).

93 See e.g. Khurrum Awan et al, Maclean's Magazine: A Case Study of Media-Propagated Islamophobia (2007), online: Canadian Islamic Congress < http://www.safs.ca/issuescases/Report_on_Macleans_Journalism.pdf $>$.

94 See News Release, "Human Rights Complaints Launched Against Maclean's Magazine” (4 December 2007), online: Canada Newswire $<$ http://cnw.ca/x92Wa>.

95 "Curb bigoted acts not free speech", Editorial, The Toronto Star (16 June 2008) [The Star, "Curb bigoted acts"].

96 The Ontario and federal cases were dismissed without a hearing in June 2008. The BC case was dismissed following a hearing on 10 October 2008.

97 Commission statement concerning issues raised by complaints against Maclean's Magazine (9 April 2008), online: Ontario Human Rights Commission < http://www.ohrc.on.ca/en/news_centre/commission-statement-concerning-issuesraised-complaints-against-macleans-magazine\#sthash.JzhYC3Jl.dpuf $>$ ("[W]hile we all recognize and promote the inherent value of freedom of expression, it should also be possible to challenge any institution that contributes to the dissemination of destructive, xenophobic opinions.").

98 Decision of the Canadian Human Rights Commission, Canadian Islamic Congress v. Rogers Media Inc. (25 June 2008), 20071008, dated June 25, 2008 [unpublished, on file with author].

99 Elmasry and Habib v Roger's Publishing and MacQueen (No 4), 2008 BCHRT 378 (CanLII). 
rights rather than protect them. According to one observer writing in the conservative American magazine, the National Review, "Canada's human-rights tribunals are best known for penalizing critics of Muslim fundamentalists." ${ }^{100}$ Underlying this commentary was an "us versus them" subtext, putting the elites who publish newspapers in the victim position ("us") and the Muslim unknowns who brought the litigation in the position of "aggressor" ("them"). The Canadian public easily identified with the "us" and accordingly dismissed, or, worse, demonized the "them."

Though it emanates from the fringe, human rights scepticism is not restricted to the libertarian extreme. It has become common for pundits of all stripes, including liberals, to slam human rights in the national media. ${ }^{101}$ The Pieters case in many respects presented a microcosm of a broader debate. The OHRC intervened to support the black lawyers. A statutory institution, the OHRC has played a variety of roles in advancing human rights in the province. Since the system overhaul of 2008, the OHRC has focused its attention on research, policy and systemic issues. Its intervention sought to assist the Court with the appropriate test for discrimination. It also highlighted the jurisprudential consensus concerning anti-black racism, and the systemic factors that underlie discrimination and shape unconscious impulses.

Intervening on the opposite side was the League for Human Rights of B'nai Brith, a long-standing Jewish service organization dedicated to "combating antisemitism, racism, and bigotry."102 In an unusual move, the League intervened in opposition to the black lawyers' claim, ${ }^{103}$ arguing that the organization was concerned about the loss of public confidence in human rights. ${ }^{104}$ The League described itself as "a group that had worked for decades to eliminate discrimination and which cooperated with the human rights commissions across the country," but in recent years it had also been the subject of an unsuccessful human rights complaint. ${ }^{105}$ As a result of its experience responding to allegations, along with perceptions of general unfairness in the system, unjust outcomes and free speech suppression, the League was concerned about the "erosion of public support" for human rights codes. ${ }^{106}$

100 Jon Leo, “Canadian Kangaroos”, National Review Online (20 June 2008), online: <http://www.nationalreview.com/articles/224817/canadian-kangaroos/john-leo>.

101 See also Rex Murphy, "Human rights meets their match: the microwave oven", National Post (5 February 2011), online: $<$ http:/fullcomment.nationalpost.com/2011/02/05/rex-murphy-human-rights-meets-its-match-the-microwave-oven/>;

The Star, "Curb bigoted acts," supra note 95 (arguing that "Parliament and the legislatures should rethink laws that have the effect of targeting opinions rather than actions").

102 B'nai Brith Canada, "League for Human Rights",,online: B'nai Brith Canada <http://bnaibrith.ca/league $>$.

103 The claimant, Selwyn Pieters, described the League's intervention to the national media as a "total betrayal of victims of discrimination." See Sarah Boesveld, "Dreadlock discrimination real: black lawyer's human rights appeal told" National Post (18 December 2012), online: <http://news.nationalpost.com/news/canada/dreadlock-discrimination-real-blacklawyers-human-rights-appeal-told $>$. League factum, supra note 75 at para 28.

105 The League was accused of promoting racial profiling of Muslims. The investigation yielded no evidence to uphold the allegations. See Brean, supra note 77.

106 League Factum, supra note 75 at paras 2-4. The Canadian Civil Liberties Association (CCLA) also publicly called for the repeal of s 13 of the Canadian Human Rights Act on free speech grounds. Michael Woods, "Hate speech no longer part of Canada's Human Rights Act" National Post (27 June 2013), online: <http://news.nationalpost.com/news/canada/canadian-politics/hate-speech-no-longer-part-of-canadas-human-rights-act> (quoting CCLA spokesperson, Cara Faith Zwibel stating, "[The CCLA] felt that given the impact that [s 13] has on freedom of expression, and given that it hasn't really proven to be a very effective method for dealing with discrimination, that it shouldn't be on the books anymore ... We really encourage countering hateful speech, rather than trying to censor it." The Canadian Bar Association, meanwhile, defended the law on the basis that it was important to curb hate speech, 
It wanted the Court to refrain from inferences and presumptions of guilt, worrying that "if tribunals allow those labels [of discrimination] to stick too easily, they will lose their meaning." 107

Indeed, the League rationalized its position by pointing to the demise of section 13 of the Canadian Human Rights $A c t^{108}$ as a casualty of human rights scepticism. Section 13 prohibited speech likely to expose identifiable vulnerable groups to hate. After lengthy and widely contested public deliberation, the hate speech provision in the Act was repealed in 2013, at least partly because of political backlash. ${ }^{109}$ According to the League, "One of the arguments raised against s. 13 was the claim that it was too difficult to defend a complaint; that a charge was akin to a conviction." 110 As a result, the League joined the chorus of opposition to s. $13,{ }^{111}$ feeling "compelled to support the law's abolition"112 despite having "once regarded the legislation as its best weapon against neo-Nazi hate propaganda." 113

\section{HUMAN RIGHTS GONE TOO FAR OR NOT FAR ENOUGH?}

These episodes hint at the powerful impact of rights. The backlash to the Maclean's case, and the League's resistance to Pieters, are also cautionary tales for human rights advocates. The claimants in these cases were no doubt motivated by a desire to see justice done. Yet, such complainants risk being treated not as genuine victims seeking redress for legal wrongs but, rather, as "those people" trying to impose their will on "us" by co-opting the human rights process. ${ }^{114}$ Much of the public discourse around the Maclean's case identified with the "victim" newspaper and journalist, against the clamorous call of law-wielding Muslims. ${ }^{115}$ Similarly, in the coverage of the Pieters case, the press highlighted Mr.

especially in the age of digital communications. Canadian Bar Association, "Bill C-304: Canadian Human Rights Act amendments (hate messages)", April 2012; online: https://www.cba.org/cba/submissions/pdf/12-25-eng.pdf

League Factum, supra note 75 at para 26. That the League has itself pursued several unsuccessful human rights processes to discredit its adversaries as "anti-Semites" apparently does not pose the same risk. For example, the League failed in its attempt to use the City of Toronto's anti-discrimination policy to ban the activist group Queers Against Israeli Apartheid (QuAIA) from marching in Toronto's Gay Pride parade. See: Andrea Houston, "Dispute panel says QuAIA can march in Pride parade", Daily Xtra (25 June 2012), online: <http://dailyxtra.com/toronto/news/dispute-panel-says-quaia-canmarch-in-pride-parade>. RSC, 1985, c. H-6 [CHRA].

109 See generally, Charlie Gillis, "Section 13: How the battle for free speech was won", Maclean's (19 June 2012), online: $<$ http://www2.macleans.ca/2012/06/19/five-years-two-tribunals-a-raft-of-secret-hearings-a-supreme-court-challengehow-the-battle-for-free-speech-was-won/>.

110 League Factum, supra note 75 at para 23.

111 Support for repealing the section came from a notably wide range of voices on the political spectrum, including a key report by liberal law professor Richard Moon, who recommended that s 13 be repealed due to the "limited potential of hate speech regulation to advance equality" and the poor fit between hate speech regulation and the anti-discrimination complaints mechanism. See Richard Moon, Report to the Canadian Human Rights Commission Concerning Section 13 of the Canadian Human Rights Act and the Regulation of Hate Speech on the Internet (October 2008), online: Social Science Research Network $<$ http://ssrn.com/abstract=1865282>.

112 League Factum, supra note 75 at para 2.

113 Gillis, supra note 109.

114 See e.g. Leo, supra note 100.

115 This discourse of weaker parties using the law to wage war on established power enjoys currency in conservative circles: Some commentators regard lawfare as an insidious tool of America's enemies, including internationalist NGOs with an agenda to promote ... [t]his easy equation of judicial processes with terrorism is startling, 
Pieters's history of litigating racial discrimination, ${ }^{116}$ while the accused law librarian easily appeared to be victim of both an unfair statutory regime and a presumption of guilt by an over-reaching rights system.

Legal victory can create tangible feelings of power shifting, for those on both sides. For members of minority groups, a legal victory can be an exhilarating vindication amid a general climate of racial animus and societal complicity that rarely affirms those members' lived experiences with inequality. ${ }^{117}$ It can also galvanize social and political action through coalition building and solidarity. ${ }^{118}$ Williams describes moments of rights affirmation as "islands of empowerment." ${ }^{119}$ For her, "[r]ights contain images of power, and manipulating those images, either visually or linguistically, is central in the making and maintenance of rights... . [T] he more dizzyingly diverse the images that are propagated, the more empowered we will be as a society." ${ }^{20}$ Rights claimants experience a sense of power when they reconstruct the images before the law, from stereotype to truth. A successful human rights decision, like Pieters, can do that.

But the value of rights vindication must be assessed in the overall context of social and political conditions. The theory of backlash suggests that strong legal victory will come with political consequences that can be regressive for the broader social justice goal. While democracy welcomes spirited public debate, human rights are, at their core, counter-majoritarian and are often at risk of being perceived as "anti-democratic". This can make the tension between what rights protection requires and what liberal-democratic institutions are prepared to do particularly acute.

\section{DELIBERATION AND PERSUASION}

Structural realities dictate that material interests will affect the content and manner of any debate, including about human rights. Thus, the spaces of public deliberation about rights provide imperfect, but useful, avenues for a society to grapple with difficult questions. Moments of polarized public debate about a contentious issue can in fact signal an impending seismic attitudinal shift that may yield tangible progress. ${ }^{121}$ In international studies, scholars have noted that a combination of rules enforcement, argumentation and persuasion can operate to indigenize international human rights norms that may

but it makes sense to those who regard lawyers invoking international law, human rights, or civil liberties as witting or unwitting agents of America's enemies.

David Luban, "Lawfare and Legal Ethics at Guantanomo" (2008) 60 Stanford L Rev 1981 at 2020-2021 [emphasis added].

116 See "National Post editorial board: Real court," supra note 81 (referring to Pieters's legal challenge to the standardized law school admission test more than 10 years earlier on the basis that it is racially discriminatory).

117 There is a rich history of members of minority groups in Canada using the courts to challenge discrimination in a variety of areas. See James W St G Walker, “Race," Rights and the Law in the Supreme Court of Canada: Historical Case Studies (Waterloo: The Osgoode Society for Canadian Legal History and Wilfrid Laurier University Press, 1997).

118 See Carmela Patrias \& Ruth A Frager, “This is Our Country, These are Our Rights': Minorities and the Origins of Ontario's Human Rights Campaigns" (March 2001) 82 Cdn Historical Rev 1 at 2 [describing how coalition-based social campaigns led to the passage of Ontario's Fair Employment Practices Act in 1951].

119 Williams, supra note 1 at 233-234.

120 Ibid.

121 Thomas Risse, Stephen Ropp \& Kathryn Sikkink, eds, The Power of Human Rights: International Norms and Domestic Practice (Cambridge: Cambridge University Press, 1999) [Describing the steps to "socializing" human rights norms]. 
previously have been resisted in localized contexts. ${ }^{122}$ The first step to socializing human rights norms is forced imposition and strategic bargaining, which is necessary to implant positive human rightsrespecting laws, even if their enforcement is unlikely and the state's commitment to them is tenuous. ${ }^{123}$ The second step is institutionalization, which is the operationalizing stage that flows from the changes implemented at the first step. Note that institutionalization of human rights norms under this model comes before the content of those norms is finally determined and embedded. Substantive details come about through an ultimate process of argumentation and persuasion. This is where the state and citizens engage in debate about contentious issues, with a view to reaching a public consensus. Under this conception, rights defenders must also engage competitively in the public marketplace of ideas, where the content of "rights" is up for negotiation. The process requires an attitude of openness to persuasion, and also to compromise. According to the theory, through this deliberative process human rights norms become thoroughly socialized. ${ }^{124}$

The international socialization model is not a perfect fit for evaluating what backlash means in domestic human rights enforcement, but it does offer some insight to interpreting the socio-political impact of strong rights decisions. It lends support to the suggestion that what is called "backlash" might actually be a foreseeable, even constructive, dynamic. High-pitch public contestation may in fact mark a transition from a stage of rights institutionalization to one of argumentation and persuasion, which if successful can lead to a new and stable public consensus.

In all of the cases examined in this article-RDS, Nassiah, Pieters and Maclean's - the claimants compelled the kind of moment Williams might describe as turning "rhetorical truth" into a "rhetorical gesture" in order to create space for the possibility of an alternative, more inclusive and more truthful "truth". The forum created by the human rights system (or court) provided a structure for asserting each claim. Regardless of the substantive result, these spaces can be seen as "islands of empowerment" for those individuals whose lives are shaped and affected in various ways by racism. ${ }^{125}$ The claims speak

122 See Brian Greenhill, "The Company You Keep: International Socialization and the Diffusion of Human Rights Norms" (2010) 54 Int'1 Studies Quarterly 127; Ryan Goodman, “Acculturation and International Human Rights Law: Toward a More Complete Theoretical Model" (2009) 20 EJIL 443; Christopher Marsh \& Daniel P Payne, "The Globalization of Human Rights and the Socialization of Human Rights Norms" (2007) BYUL Rev 665; Ryan Goodman \& Derek Jinks, "How to Influence States: Socialization and International Human Rights Law" (2004) 54 Duke LJ 621; Risse, Ropp \& Sikkink, supra note 121.

123 Risse, Ropp \& Sikkink, ibid [outlining a socialization paradigm that advances in three steps for effective entrenchment of international human rights norms in local culture].

124 Ibid.

125 Regarding anti-black racism, see Tanovich, supra note 40 and Henry, supra note 74. Regarding Islamophobia, see Wayne Hanniman, "Canadian Muslims, Islamophobia and National Security” (2008) 36 Int'1 J L, Crime \& Jus 271 at 273-275 [describing how Canadian Muslims have experienced distrust and discrimination within Canadian society since 9/11]; Sherene Razack, Casting Out: The Eviction of Muslims from Western Law and Politics (Toronto: University of Toronto Press, 2008) at 33 [describing the idea that Muslims are associated with "terrorism" as one of the most prevalent stereotypes today]; Ontario Human Rights Commission, "Policy and Guidelines on Racism and Racial Discrimination"(June 2005), online: <http://www.ohrc.on.ca/sites/default/files/attachments/Policy_and_guidelines_on_racism_and_racial_discrimination.pdf $>$ at 10 [describing Islamophobia as a "contemporary and emerging form of racism against Muslims in Canada"]; Gerard Bouchard \& Charles Taylor, "Building the Future: A time for Reconciliation" (2008), online: <http://collections.banq.qc.ca/ark:/52327/bs1565996> at 232 [concluding that "Muslims and, in particular, Arab Muslims, are, with Blacks, the group most affected by various forms of discrimination" in Quebec]; Amnesty International, "Matching International Commitments with National 
truths in and of themselves. This is where the power of such claims reside, but also from where the impulse to backlash emerges. The member of a racialized group who makes a claim of discrimination without anything short of a smoking gun may be viewed as an agitator, even an aggressor, who turns others into victims by unleashing human rights upon them.

This defensive response to allegations of discrimination grows out of an unfounded and illogical assumption that most people hold non-discriminatory attitudes. While the legal system imposes the burden of proof on the one who alleges a wrong, nobody is expected to "prove" the background facts, including the "backdrop of hidden, contestable assumptions about which we could never function, but which necessarily predetermine in large measure, the results reached." ${ }^{26}$ There is, therefore, no logical reason for adjudicators to begin from a factually suspect starting point of race-neutrality, especially in the human rights context, where liability is not contingent upon intent or state of mind. Fact-finders do not necessarily abandon the requirement that the applicant meet the "more likely than not" burden of proof applicable in discrimination cases when they ask, as the HRTO did in Pieters, for an explanation from the respondent about their state of mind and conduct. Until courts and tribunals move away from assuming incorrect background facts, adjudication will almost always begin from the false presumption of a race-neutral society. ${ }^{127}$ Cases like Pieters transform these presumptions and compel future decision makers to consider race when it is relevant, and to take notice of the background social fact of systemic racism. Perhaps by naming unwitting discriminators, like the unremitting law librarian, human rights law can hope to serve as an unconscious, if not conscious, deterrent.

It is, at the same time, quite important not to overstate the backlash phenomenon or its implications. ${ }^{128}$ In the US, backlash theories were tempered almost as soon as they were tested. American backlash theorists, who mostly wrote about failures in implementing racial equality as prescribed by Brown, reached the opposite conclusion when they assessed the movement towards gay rights. ${ }^{129}$ Recent research suggests that, contrary to initial concern about resistance to early gay rights litigation, it appears that public opinion towards acceptance of gay marriage actually accelerated during the period of backlash. ${ }^{130}$ On abortion, it has recently been shown that political realignment, not

Action: A Human Rights Agenda for Canada" (December 2012), online: $<$ http://www.amnesty.ca/sites/default/files/canadaaihra19december12.pdf $>$ at 24 [finding that "Arab and Muslim communities in Canada have understandably come to worry that their rights as citizens might not be protected as equally as the rights of other citizens."]

126 Jane E Baron, "Resistance to Stories" (1994) 67 S Cal L Rev 255 at 256.

127 See, e.g., Jordan Hauschildt, "Blind Faith: The Supreme Court of Canada, s. 24(2) and the Presumption of Good Faith Police Conduct" (2010) 56 Crim LQ 469 at 518-521 [arguing that "Many courts refuse to accept particular instances of racial profiling, choosing instead to ignore facts that are strongly indicative of the racial undertones of officer-accused interactions"].

128 Carle, supra note 26 at 194. Carle challenges the theory that the risk of backlash requires scepticism about rights litigation:

The descriptive conclusion that no good has been achieved as the result of prior efforts at social reform produces the normative conclusion that nothing ought to be tried, because such efforts never produce improvements, and may produce a worse state of affairs than originally existed. Such broad conclusions lead to a state of apathy or resignation worse than a failed experiment.

129 Klarman, From the Closet, supra note 20.

130 Ibid. 
backlash to litigation, better explains the timing and shape of political polarization around that issue in the United States. ${ }^{131}$

In Canada, the Maclean's issues arguably attracted disproportionate media attention because the press was directly affected. Almost every major media publication in the country expressed concern about protecting press freedom from human rights. The fact that large segments of the public identified with the issue does not necessarily suggest that the public were concerned about the issue prior to it being prioritized by the self-interested media. In Pieters, there was far less coverage of the case, and minimal backlash. In Ontario, Tim Hudak won the Conservative Party leadership in 2009 on the energy of human rights scepticism, committing himself to abolishing the HRTO, which he once called a "kangaroo court." ${ }^{\prime 132}$ When federal Conservative MP Brian Storseth introduced the private member's bill to repeal s. 13 of the CHRA, he described the federal tribunal with surprising contempt as "a quasi-judicial, secretive body that takes away your natural rights as a Canadian." 133 In Ontario, Tim Hudak's subsequent reversal of his promise to abolish the HRTO suggests that he may have over-played the hand of human rights scepticism. It also suggests that, despite intense public contestation about form and content, human rights may be sufficiently entrenched in the social fabric of Ontario to forestall any political threat of legislative repeal. At the federal level, the call for human rights reform halted at the repeal of the hate speech provision, while the core anti-discrimination protections remain in force.

Indeed, for better or worse, human rights remain an integral part of the legal and institutional framework. More importantly, human rights language has been normalized and basic principles have been embedded in general best practices in employment, services, contracts and housing. While it may once have been acceptable, even encouraged, to openly crack jokes or utter slurs about people of various ethnicities, or to use sexual humour and innuendo, such behaviour is now widely condemned in regulated spaces, and prohibitions are often enforced with consequences. This culture shift has occurred at least in part due to the existence of human rights law and institutions.

\section{CONCLUSION}

Under Ontario's direct access tribunal model, which launched in 2008, virtually anyone can lodge a claim and compel almost anyone else to respond to allegations of discrimination. Frequent respondents in human rights cases include small-business owners, independent professionals, low- and mid-level managers and public-service workers. Such individuals exercise some degree of situational power advantages in a particular setting (e.g., as an employee's supervisor or frontline service provider), but

131 Linda Greenhouse \& Reva B Siegel, "Backlash to the Future? From Roe to Perry" (2013) 60 UCLA L Rev Discourse 240 at 245.

132 Post Editorial, "You call this," supra note 78. See also Robert Benzie, "Rift opens in Tory race over human rights agency", The Toronto Star (21 May 2009), online: <http://www.thestar.com/news/ontario/2009/05/2-

1/rift_opens_in_tory_race_over_human_rights_agency.html $>$. Hudak quietly dropped his plan to scrap the human rights system a few months before the election, instead committing to "fix" it. See Rob Ferguson \& Robert Benzie, "McGuinty calls Hudak on human rights flip-flop", The Toronto Star (10 May 2011), online: <http://www.thestar.com/news/canada/2011/05/10/meguinty_calls_hudak_on_human_rights_flip-flop.html $>$. The Conservative Party lost the Ontario election in October 2011.

133 Michael Woods, "Hate speech no longer part of Canada's human rights act", National Post (27 June 2013), online: National Post <http://news.nationalpost.com/2013/06/27/hate-speech-no-longer-part-of-canadas-human-rights-act/>. 
they are mostly people just like anybody else. Such individuals, when accused of discrimination, feel oppressed by human rights. This is a cost to consider, but should be viewed in the broader context of increasing access to justice and promoting the aspirations of the Code.

In the final analysis, exposing hard-working, middle-class, decent individuals as unwitting discriminators will not cure society of its structural ills. Whatever resolution a human rights case may deliver to a successful applicant, there remains little debate that litigation alone cannot solve social problems; at best, it fixes (parts of) an individual's experience of injury, and mitigates (some of) the harms caused by social disadvantage. The types of social problems that are not substantially affected by human rights litigation include negative attitudes, values, culture and the economic order. Cultural shifts occur within society, often detached from or despite the law. Political engagement and persuasion can achieve more by way of attitude shifting than can strong rights adjudication. ${ }^{134}$ Meanwhile, the foundational arrangements around resource and wealth distribution will not be significantly impacted or altered by human rights litigation. Indeed, human rights operate within political, legal and institutional constraints that define the scope of possible transformation. Without a re-ordering of social and economic foundations, inequality of some form is likely to remain an essential feature of Canadian race relations. A liberal reform mechanism, such as anti-discrimination law, can provide at best a mitigating outlet to offset the harms caused by underlying conditions that are bound up in the production and perpetuation of systemic inequality.

If human rights litigation is not capable of producing significant systemic change or social transformation, what value do human rights bring to the question of racial emancipation? Cases like Pieters provide moments to reflect and acknowledge the truth of lived experiences with race and power. They offer the occasion to appropriate rhetorical frames, and to layer subjectivities in order to affirm the racialized experiences with the law that are too often muted by established norms of legal process. The debate about whether adjudication is the best avenue for rights definition and redress will no doubt continue. The idea that rights provide the possibility of "islands of empowerment" is better than losing hope or seeking solace in failure. Cases like Pieters and Maclean's demonstrate that members of structurally disadvantaged groups can access the justice system and compel engagement by more powerful actors, even if achieving systemic racial equality remains a more distant goal.

134 See Ryan Goodman, Derek Jinks \& Andrew K Woods, eds, Understanding Social Action, Promoting Human Rights (New York: Oxford University Press, 2012). 